\title{
Transferi profesionalnih sportaša: financijski i porezni učinci
}

DANIJELA KULIŠ Institut za javne financije JOSIP FRANIĆ Institut za javne financije

\section{UVOD}

Interes javnosti za sport nije usmjeren samo na sportska natjecanja i rezultate, nego se $s$ jednakom - ako ne i većom - pozornošću prate i zbivanja izvan sportskih terena. Financijsko poslovanje sportskih klubova, netransparentne dotacije iz javnih izvora, prihodi igrača, naknade za prelaske (transfere) igrača, porezne obveze te nepodmirene obveze prema vjerovnicima učestale su teme sportskih vijesti. Sveprisutnom komercijalizacijom, sport je postao i značajan segment gospodarstva. Kao jedan od visoko profesionaliziranih sportova nogomet je, kako u svijetu tako i u Hrvatskoj, postao i unosna poduzetnička zona.

Budući da se financiranje sporta $u$ Hrvatskoj ${ }^{\mathrm{T}} \mathrm{u}$ najvećem dijelu oslanja na javna (proračunska) sredstva, razumljiv je interes javnosti i pitanja kako posluju profesionalni sportski klubovi s najvećim udjelima u dodijeljenim javnim sredstvima. Zakonom o sportu, "sportske su djelatnosti od posebnog interesa za Republiku Hrvatsku”, a Ustav ${ }^{3}$ izričito govori o dužnosti države da "potiče i pomaže skrb o tjelesnoj kulturi i sportu". Većina pravnih osoba u sportu ustrojene su kao

\footnotetext{
I Institut za javne financije je za potrebe Ministarstva znanosti, obrazovanja i sporta (MZOS) u 2OI2. izradio studiju "Financiranje sporta $u$ Republici Hrvatskoj s usporednim prikazom financiranja u Europskoj uniji”, iz koje su ovdje preuzeti neki dijelovi teksta. Voditeljice istraživanja bile su Danijela Kuliš i Vesna Lendić Kasalo. Cjelovita studija je dostupna na mrežnoj stranici MZOS-a: <http://public. mzos.hr/Default.aspx?sec=2379>.

2 Članak I., st. 2. ZS-a.

3 Članak 69.
}

udruge. U Registru udruga krajem veljače 2013. bile su upisane 16.453 sportske udruge (34\% svih udruga u Hrvatskoj), od čega je 2.766 nogometnih klubova. Zakon o udrugama kao opći i Zakon o sportu kao posebni zakon, uređuju opća pitanja osnivanja, ustroja, pravnog položaja, registracije i prestanka rada sportskih udruga i svih njihovih oblika udruživanja. Zakon o sportu propisuje da se sportski klubovi za natjecanje mogu ustrojiti i kao trgovačka društva, odnosno da se obvezno ili dragovoljno mogu preoblikovati iz udruge u sportsko dioničko društvo, te se tada na njihovo poslovanje primjenjuju odredbe Zakona o trgovačkim društvima.

Većina nogometnih klubova u Hrvatskoj udruge su građana ustrojene po Zakonu o udrugama, a samo četiri kluba su sportska dionička društva (HNK Hajduk, HNK Cibalia, NK Istra 196I. i HNK Rijeka) ${ }^{4}$, nastala uglavnom sukladno odredbama Zakona o sportu o obveznom preoblikovanju. Međutim, natjecanje u Prvoj hrvatskoj nogometnoj ligi, pored primarno sportske, predstavlja i gospodarsku aktivnost. Poslovanje udruga temelji se na neprofitnim načelima, dok je stjecanje dobiti primarno obilježje gospodarskih aktivnosti.

U drugom dijelu rada prikazuje se pravni ustroj profesionalnih sportskih klubova $\mathrm{u}$ RH i propisani sustavi financijskog praćenja i izvještavanja. Na temelju ustrojbenog oblika pravnog subjekta određena su i pravila

4 U procesu preoblikovanja su još NK Osijek i HNK Šibenik. Za više detalja vidjeti na službenim mrežnim stranicama tih klubova. 
poslovanja, financijskog izvještavanja i oporezivanja, te odgovornost za financijske rezultate. U trećem dijelu razmatra se oporezivanje, posebice transfera u nogometu. Visoki iznosi naknada za transfer nogometaša ukazuju da u nogometu ipak vladaju tržišni zakoni ponude i potražnje, te se razmatra porezni status prihoda sportske udruge. Jesu li naknade za transfere $u$ poreznom smislu izjednačene s istovrsnim transakcijama i prihodima ostalih subjekata jednakoga pravnog statusa pri oporezivanju dobiti, dohotka i dodane vrijednosti? U četvrtom i petom dijelu prikazan je ustroj i poslovanje nogometnih klubova, te pravila vezana za transfere u nekim zemljama EU-a, gdje kao i u Hrvatskoj ustroj kluba određuje njegov porezni status.

\section{USTROJ PROFESIONALNIH SPORTSKIH KLUBOVA} U HRVATSKOJ I FINANGIJSKO IZVJEŠTAVANJE

Zakon o sportu propisuje da "djelatnost sudjelovanja" u sportskom natjecanju mogu „obavljati” fizičke i pravne osobe. Neovisno o pravnom obliku (udruga za natjecanje ili dioničko društvo), sportski klubovi mogu imati profesionalni ${ }^{5}$ ili amaterski status. Bez obzira na ustroj, profesionalni sportski klub se obvezno upisuje u Registar profesionalnih sportskih klubova koji vodi Ministarstvo znanosti, obrazovanja i sporta (MZOS). Registar je javan, u elektroničkom je obliku i svatko ima pravo uvida u podatke, bez dokazivanja pravnog interesa, te može zahtijevati izvadak iz Registra. Prema podacima na mrežnoj stranici MZOS-a (I. veljače 2OI3.), u nogometu je registrirano I5, u košarci 5, a u rukometu samo jedan profesionalni sportski klub ${ }^{6}$, dok su taj status izgubila 4 nogometna i jedan košarkaški klub.

Povjerenstvo za profesionalne sportske klubove, koje djeluje pri MZOS-u kao stručno tijelo koje prati djelatnost profesionalnih sportskih klubova, vodi evidenciju o dokumentaciji koju su mu ti klubovi dužni dostavljati. Povjerenstvo daje suglasnost na izbor revizora koji treba utvrditi jesu li u profesionalnom sportskom klubu ostvareni uvjeti za pokretanje stečajnog postupka, odnosno za obvezno preoblikovanje u sportsko dioničko društvo. Pravilnik o djelokrugu i načinu rada Povjerenstva za profesionalne sportske klubove daje Povjerenstvu i ovla-

5 Profesionalni status ima sportski klub koji je osnovan radi obavljanja sportske djelatnosti sudjelovanja u sportskom natjecanju, ukoliko više od 50\% registriranih sportaša u seniorskoj konkurenciji (na listi koju vodi odgovarajući nacionalni sportski savez) ima sklopljen ugovor o profesionalnom igranju ili ugovor o radu sa sportskim klubom ili obavlja samostalnu sportsku djelatnost sudjelovanja u sportskom natjecanju, odnosno, ako sportski klub ispunjava uvjete za stjecanje profesionalnog statusa sukladno pravilima odgovarajućeg nacionalnog sportskog saveza.

6 To znači da tek I\% nogometnih klubova u Hrvatskoj ima profesionalni status; prema podacima na mrežnoj stranici Hrvatskog nogometnog saveza, u sustavu natjecanja u Hrvatskoj registrirano je I.420 nogometnih klubova u kojima igra 650 profesionalnih nogometaša (od ukupno II8.3I6 registriranih igrača, u seniorskoj kategoriji ih je 44.I62. sti s neposrednim utjecajem na financijsko poslovanje profesionalnih sportskih klubova.

Naime, profesionalni sportski klubovi moraju jednom godišnje Povjerenstvu podnijeti račun dobiti i gubitka, izvješće o registriranim sportašima seniorske momčadi, godišnje financijsko i revizorsko izvješće, plan poslovanja za iduću poslovnu godinu, izvješće o članovima kluba i članovima tijela kluba. Posljedice nepoštivanja obveza općim aktom utvrđuje nacionalni savez.

Zakon o sportu prilično detaljno uređuje osnivanje i djelovanje sportskih klubova - sportskih dioničkih društava (s.d.d.) na koje se supsidijarno primjenjuje i Zakon o trgovačkim društvima i drugi propisi za dionička društva. Sportska dionička društva mogu biti osnovana kao nova trgovačka društva, odnosno preoblikovana iz sportskog kluba - udruge za natjecanje (bez obzira imaju li profesionalni ili amaterski status), bilo dragovoljno, bilo postupkom obveznog preoblikovanja. Obavezno se preoblikovanje provodi kada je riječ o profesionalnom sportskom klubu u nogometu, košarci i rukometu upisanom u Registar, kod kojega je temeljem revizije utvrđeno da postoje uvjeti za pokretanje stečajnog postupka prema posebnim propisima?.

Postoje li u Hrvatskoj uvjeti potrebni za uspješno preoblikovanje nogometnih klubova u sportska dionička društva? Glavni preduvjet u najboljim europskim ligama bio je postojanje dovoljnog broja zainteresiranih tržišnih sudionika (navijača koji kupuju ulaznice i klupske suvenire, sponzorâ, televizijskih postaja koje plaćaju prava prijenosa utakmica ili privatnih ulagača) spremnih za izdvajanja sredstava za aktivnosti vezane uz pojedini klub. Ne postoje egzaktni podaci ogospodarskojpotražnji za nogometom u Hrvatskoj koja bi klubovima nakon preoblikovanja omogućila zadovoljavajuće izvore financiranja. Jesu li lokalne zajednice - kao najveći donatori, ali i vjerovnici - zainteresirane biti glavni dioničari lokalnih nogometnih klubova, ili se očekuje da to učine privatni poduzetnici koji u tome vide stanoviti profit ili pak navijači kao mali dioničari koji svojim ulozima žele dokazati koliko im je stalo do opstanka voljenog kluba?

Sustav financijskog izvještavanja za sve neprofitne organizacije, pa tako i za sportske udruge i ustanove, uređen je Uredbom o računovodstvu neprofitnih organizacija ${ }^{8}$. Za objektivnost i realnost financijskih izvješća odgovara zakonski zastupnik - čelnik udruge i ustanove. Izvješća se predaju Državnom uredu za reviziju i FINA-i, za potrebe Ministarstva financija i Državnog zavoda za statistiku. Međutim, navedena financijska izvješća nisu javno do-

7 Više o preoblikovanju vidi Vuković (2OII).

8 Članci 65. - 72. 
stupna. Ipak, primjena Zakona o fiskalnoj odgovornosti i Uredbe o sastavljanju i predaji izjave o fiskalnoj odgovornosti i izvještaja o primjeni fiskalnih pravila trebali bi imati velik posredan utjecaj na nadzor, ponajprije nad trošenjem sredstava za one neprofitne organizacije koje se dijelom financiraju iz državnog ili lokalnog proračuna. S druge strane, godišnja revizorska izvješća sportskih dioničkih društava javno su dostupna putem sudskog registra i u njima se na transparentan način vide i prihodi od transfera i porezne obveze.

\section{OPOREZIVANJE U SUSTAVU SPORTA - POREZNI STATUS NAKNADA ZA PRIJELAZ IGRAǦA}

Porezni položaj subjekata u sportu ovisi o njihovu pravnom obliku i ciljevima djelovanja. Zakoni rijetko propisuju poseban porezni položaj za subjekte u sportu, već im položaj ovisi o njihovom pravnom statusu, pa se shodno tome na nj primjenjuju i odgovarajuća porezna pravila. Bitno je, također, djeluje li subjekt radi ostvarivanja profita ili ne - ako je riječ o profitnoj organizaciji, primjenjivat će se porezna pravila kao za svaki drugi gospodarski subjekt. Ukoliko, međutim, cilj djelovanja organizacije nije ostvarivanje profita, hrvatsko zakonodavstvo, kao i većina europskih, propisuje primjenu stanovitih poreznih pogodnosti koje vrijede i za sve ostale neprofitne organizacije.

Sukladno važećim propisima, a i nacrtu novog Zakona o udrugama koji je u postupku javnog savjetovanja, sportski klubovi koji djeluju kao udruge - neprofitne pravne osobe - mogu obavljati djelatnosti kojima se stječe prihod sukladno statutu udruge i sukladno posebnim propisima kojima se uređuju uvjeti za obavljanje te djelatnosti. Međutim, zbog svog neprofitnog karaktera, udruga ne smije obavljati djelatnosti radi stjecanja dobiti za svoje članove ili treće osobe. Ostvareni višak prihoda nad rashodima mora se koristiti isključivo za obavljanje i unapređenje djelatnosti kojima se ostvaruju ciljevi udruge utvrđeni statutom.

Iako sukladno Zakonu o porezu na dobit ${ }^{9}$, određeni neprofitni pravni subjekti - među kojima su i sportski klubovi, sportska društva i savezi - nisu obveznici poreza na dobit, postoji razumljiva iznimka ${ }^{\mathrm{Io}}$. Ukoliko osobe iz stavka 6. obavljaju gospodarstvenu djelatnost, a neoporezivanje te djelatnosti bi dovelo do stjecanja neopravdanih povlastica na tržištu, Porezna uprava je ovlaštena da na vlastitu inicijativu, ili na prijedlog drugih poreznih obveznika ili druge zainteresirane osobe, rješenjem utvrdi da su navedene osobe obveznici poreza na dobit za tu djelatnost. Dakle, ukoliko neka sportska udruga obavlja gospodarstvenu djelatnost u skladu s navedenim, dobit joj

9 Članak 2., st. 6.

IO Članak 2., st. 7 . može biti oporezovana sukladno rješenju nadležne Porezne uprave.

Udruge, također, pod određenim uvjetima i na temelju rješenja Porezne uprave mogu postati obveznici PDV-a za isporuku dobara i obavljanje usluga, ali podaci o tome su zaštićeni poreznom tajnom, te za potrebe ovog rada nije bilo moguće doći do informacije koliko je nogometnih klubova u sustavu PDV-a, odnosno, koliko ih je obveznik poreza na dobit.

Pitanje prihoda od naknada za prijelaz sportaša iz jednog u drugi klub često je vezano za nogometaše i nogometne klubove, bez obzira djeluju li kao udruge ili sportska dionička društva. Na koji se način prihodi od transfera prikazuju u financijskim izvješćima hrvatskih profesionalnih sportskih klubova koji djeluju kao udruge i jesu li predmetom porezne obveze? Financijska izvješća neprofitnih organizacija se nažalost ne objavljuju, pa nije moguće ustanoviti kako se i pod kojim stavkama knjiže navedeni prihodi. Uvidom u godišnje financijsko izvješće s.d.d. Hajduk ${ }^{\mathrm{II}}$ vidljivo je da se prihod od transfera knjiži u stavci prihodi od prodaje, pri čemu prihodi od transfera čine $70 \%$ ukupnih prihoda u 2 OII.

Status transfera može se razmatrati s gledišta oporezivanja dobiti i PDV-a kada je u pitanju obveza kluba, ali i s gledišta poreza na dohodak $u$ smislu porezne obveze igrača na prihod ostvaren od transakcije, odnosno na prihod njihovih menadžera, ostvaren od provizije na transfere.

\section{Transferi nogometaša NK Dinamo u strane nogometne klubove}

Čl. 67. Općeg poreznog zakona (NN, I27/Oo., 86/OI. i 150/O2.), propisano je da porezni obveznik i druge osobe moraju poreznom tijelu dati obavijesti potrebne za utvrđivanje činjeničnog stanja bitnog za oporezivanje.

Porezna uprava je od nogometnog kluba Dinamo zatražila sve potrebne podatke i dokumentaciju vezanu za transfere nogometaša. Temeljem sklopljenih ugovora, porezne obveze ovise o karakteru isplate. Stoga, ako je ugovorom određeno da se isplata obavlja fizičkoj osobi, prilikom oporezivanja primjenjuju se odredbe Zakona o porezu na dohodak (NN, I77/O4.), ako je ugovorom određeno da se isplata obavi pravnoj osobi, prilikom oporezivanja će se primijeniti odredbe Zakona o porezu na dobit (NN, 177/O4., 90/O5. i 57/06.).

Dostupnona: htttp://www.mfin.hr/hr/novosti/transferi-nogometasa-nk-dinama-u-strane-nogometne-kluboveo6-o8-2007> (6. kolovoza 2007.)

II Dostupno na <https://sudreg.pravosudje.hr/ registar/f?p=I5O:28:862124408483223::NO:28:P28_SBT_ MBS:060250783>. 
S gledišta poreza na dobit, dobit je - prema definiciji razlika između prihoda i rashoda. Je li odšteta/naknada prilikom prodaje igrača (transfera) prihod što na kraju godine može rezultirati ostvarivanjem dobiti ${ }^{\mathrm{I2}}$ kluba koji je prodao igrača? Može li takav klub biti neprofitna udruga koja obavlja gospodarsku djelatnost? Sukladno propisima, nedvojbeno može, ali prema svim ekonomskim kriterijima, prodaja igrača nipošto nije neprofitna, nego gospodarska djelatnost. Nogometni klubovi s igračima potpisuju ugovore s određenim trajanjem. Ako ugovorom vezani igrač želi promijeniti klub prije isteka ugovora, klubovi mogu pregovarati o naknadi koju "starom" klubu isplaćuje klub u koji je igrač prešao. To je poslovni odnos između dva kluba. Stoga Porezna uprava (čl. 2. Zakona o porezu na dobit), na vlastitu inicijativu ili inicijativu drugih poreznih obveznika, odnosno drugih zainteresiranih strana, a zbog narušavanja načela porezne pravednosti i jednakosti, rješenjem može utvrditi da je riječ o gospodarskoj djelatnosti. Zakon o sportu (nogometnim) klubovima omogućuje da budu udruge građana, ali s obzirom na odredbe Zakona o porezu na dobit, u svakom je pojedinačnom slučaju potrebno ispitati i utvrditi radi li se o obavljanju profitne ili neprofitne djelatnosti.

Sportski klubovi u Hrvatskoj - registrirani kao sportske udruge - uglavnom nisu obveznici poreza na dobit, ali mogu biti u sustavu PDV-a. Prihodi sportskog kluba (npr. od sponzora, za usluge promidžbe ili prava emitiranja) mogu biti viši od 230.000 kuna, što je važeći zakonski prag za ulazak u sustav PDV-a, te stječu zakonsku obvezu ulaska u sustav PDV-a.

Za utvrđivanje poreznog tretmana transfera nogometaša (Jelić, 20Io.) treba analizirati odredbe Zakona o PDV-u u dijelu koji definira predmet oporezivanja ( $\mathrm{u}$ ovom primjeru usluge) $\mathrm{i}$ status poduzetnika, te $u$ pravnom smislu definirati stvarni oblik pravnog posla o kojemu je riječ.

Prema Zakonu o PDV-u, oporezuju se sve isporuke dobara i usluga koje obavi poduzetnik - porezni obveznik u sklopu svoje poduzetničke djelatnosti u tuzemstvu, uz naknadu. Opći pojam usluge kao predmeta oporezivanja (čl. 4., st. I. Zakona) propisuje da su „obavljene usluge sve one usluge koje se ne smatraju isporučenim dobrima”. Međutim, Zakonom je detaljno i vrlo široko određeno definiranje usluga (prepuštanje dobara na uporabu i korištenje - najam ili zakup, prijenos imovinskih prava kao što je prijenos i osiguranje prava na

I2 U nekim zemljama EU-a (Italija, UK), u skladu s preporukom FIFA-e i UEFA-e, na takav se prihod plaća porez na dobit. U tim je zemljama također propisano da profesionalni klubovi moraju biti registrirani kao tvrtke, odnosno dionička društva. patente, pronalazačka prava, prava industrijskog vla sništvai slična prava, trpljenje neke radnje, suzdržavanje od neke radnje i dr.). Iz toga proizlazi da su i transferi, tj. naknade za obavljenu uslugu prelaska sportaša predmet oporezivanja, uz uvjet da je takvu uslugu obavio poduzetnik u sklopu obavljanja svoje gospodarske djelatnosti. Da bi pravna ili fizička osoba bila poduzetnik u smislu Zakona o PDV-u, nije uvjet da se smatra poduzetnikom i prema drugim zakonima i nije bitno je li riječ o udruzi, ustanovi ili trgovačkom društvu. Bitno je da ostvaruje prihod, jer je PDV porezni oblik kojim se oporezuje promet dobara i usluga, a ne rezultat gospodarske djelatnosti. Nogometni, ali i ostali sportski klubovi, obavljaju isporuke dobara i usluga (prodaju ulaznice, klupske suvenire, ostvaruju naknade za prelazak igrača, za iznajmljivanje prostora i sl.) i u tom su smislu poduzetnici, a porezni obveznici postaju od I. siječnja iduće godine ako u prethodnoj kalendarskoj godini obave oporezive isporuke dobara i usluga $u$ iznosu većem od 230.000 kuna.

Pravni oblik transfera vidljiv je iz mišljenja Porezne uprave $^{\mathrm{I}}$ : Kad sportski klub - obveznik PDV-a - sporazumno dopušta igraču prelazak u drugi klub, odriče se prava koja ima prema igraču i za to prima naknadu. Odricanje od prava, predstavlja u smislu odredbe članka 4. Zakona o PDV-u uslugu koja je predmet oporezivanja. Prema tome, kada se jedna ugovorna strana odriče svoga ugovornog položaja, a druga za taj odustanak plaća naknadu, očito je riječ o usluzi (u smislu Zakona o PDV-u).

Sve navedeno odnosi se na transfere igrača u Hrvatskoj. Gleda li se usluga transfera s motrišta opće usluge, tada je mjesto oporezivanja u tuzemstvu, prema mjestu davatelja usluge. Daje li domaći klub naknadu za transfer inozemnom klubu, obračun i plaćanje PDV-a obavlja se u državi u kojoj je sjedište inozemnog sportskog kluba. Ukoliko se gleda s motrišta primatelja usluge, tada je u transakcijama s inozemstvom porezni obveznik inozemni poduzetnik.

Da li sportski klubovi - obveznici PDV-a - obračunavaju PDV na naknade za transfere unutar Hrvatske?

Budući da oporezivanje prelaska igrača, odnosno naknada za taj prelazak kao predmet oporezivanja nije nigdje izričito navedeno, ni u hrvatskom Zakonu o PDV-u, a ni u europskoj Direktivi o PDV-u, pitanje je kako se postupa u praksi. No iz sadržaja takve transakcije i uz primjenu odredaba i definicija pojma usluge i poduzetnika, odnosno poreznog obveznika, nedvojbeno proizlazi da je riječ o obavljenoj usluzi koja je predmet oporezivanja (Javor, 2007:II9).

I3 Mišljenje Porezne uprave, klasa 4IO-19/03-OI/384 od 27. veljače 2007. 
Obavljanje sportske djelatnosti fizičkih osoba podliježe porezu na dohodak i prirezu poreza na dohodak te plaćanju doprinosa za obvezna osiguranja. Ovisno o načinu na koji obavljaju djelatnost, mogu biti obveznici poreza na dohodak od nesamostalnog rada (zaposleni i umirovljenici), od samostalnih zanimanja i od drugog dohotka.

Ukoliko sportaš ima profesionalni ugovor, riječ je o radnom odnosu u kojemu ostvaruje dohodak od nesamostalnog rada (plaću), na što se primjenjuju opća pravila o oporezivanju dohotka, kao i za sve ostale porezne obveznike. Poslodavac je dužan, uz isplatu plaća, obračunati i uplatiti pripadajuće doprinose, te porez i prirez.

Među fizičkim osobama u sustavu sporta, Zakon o sportu prepoznaje i menadžere u sportu koji su prema pravilima nacionalnog saveza ovlašteni posredovati pri prelasku sportaša iz jednoga u drugi sportski klub i imaju pravo na dio prihoda ostvaren obavljanjem te djelatnosti.

Premda se nigdje izrijekom ne navode kao vrsta dohotka, primici fizičkih osoba od naknada za transfere su oporezivi i oporezuju se ovisno o načinu na koji obveznik obavlja djelatnost (nesamostalnim ili samostalnim radom ili kao samostalno zanimanje).

\section{TRANSFERI SPORTAŠA U EUROPSKOJ UNIJI}

Europska komisija je posvetila veliku pozornost transferima sportaša. U dokumentu "Razvoj europske dimenzije u sportu" (European Commission, 2OII), naglašena je obveza EU-a u poticanju, koordinaciji i uspostavi mjera za razvoj i unapređenje sporta zemalja članica, uz potrebu temeljitog preispitivanja transfera kako s pravnog tako is ekonomskog gledišta.

Na mrežnoj stranici EU-a objavljena je studija "Ekonomski i pravni aspekti transfera igrača" (European Commission, 2013) koja razmatra pravne, ekonomske i društvene aspekte sustava transfera većine europskih sportskih klubova, posebice nogometnih i košarkaških.

Ukupan iznos za transfer 18.300 nogometaša u EU-u u sezoni 20Io/2OII. iznosio je oko 3 mlrd. eura, a košarkaša 27 mil. eura. U razdoblju od 1995. do 20II. broj transfera povećao se za više od tri puta, a iznosi naknada povećani su gotovo 7,5 puta.

Pravni okvir sustava transfera donose krovna sportska tijela radi osiguravanja pravednih i ujednačenih uvjeta sportskih natjecanja, prema načelima da svaki sudionik treba imati jednaku mogućnost pobjeđivanja i da ni na koji način nije diskriminiran. Uvažavajući specifičnosti sporta, EU zakonodavstvo je imalo značajan utjecaj na razvoj i definiranje pravila u korist mobilnosti igrača, dok nacionalna zakonodavstva uređuju sva pitanja ustroja i poslovanja sportskih klubova, radnih odnosa i oporezivanja. Pravila kojima se uvodi veća transparentnost transakcija vezanih uz transfere, doprinijet ce i učinkovitijoj borbi protiv zlouporaba i općenito boljem upravljanju u nogometu.

Istraživanje ukazuje da je na razini EU-a i u zemljama članicama povećana natjecateljska nejednakost (smanjena je konkurentnost), te da važeća pravila nisu dovoljno učinkovita u sprečavanju nejednakosti u sportskim natjecanjima.

Stoga je pravednijom preraspodjelom potrebno poticati jednake natjecateljske uvjete svih sportskih klubova, ograničavati prekomjerno visoke naknade, jačati sustav solidarnosti i poboljšati upravljanje i transparentnost u transakcijama, te provoditi mehanizme pravednog rješavanja sporova.

EU komisija je preporučila da bi "prenapuhane" naknade za transfere mogle biti predmetom neke vrste fair play poreza kojim bi se preraspodijelio novac između bogatih i onih manje bogatih klubova i amaterskog sporta.

Koncentracija financijske snage transfera svela se na mali broj europskih nogometnih klubova iza kojih stoje bogati ulagači, a samo $2 \%$ ukupnih naknada od transfera prolazi kroz klubove niže lige. Stoga financijska snaga kluba značajno utječe na konkurentnost, pa u konačnici i na sportske rezultate.

Naglašava se i potreba unapređenja suradnje s javnom vlašću i izgradnja zakonodavnog okvira u kojem bi bila jasno određena pravila za sprečavanje kriminalnih djelatnosti (pranje novca, utaja i izbjegavanje poreza, namještanje sportskih rezultata) koje se često vežu uz sport.

\section{USTROJ NOGOMETNIH KLUBOVA U NEKIM EUROPSKIM DRŽAVAMA}

Proces preoblikovanja nogometnih klubova iz neprofitnih organizacija $u$ tržišno orijentirane subjekte, $u$ najboljim se europskim ligama odvijao tijekom 1980-ih i 1990-ih godina. Na najvišim razinama nacionalnih liga, nogomet se postupno pretvorio u krupni biznis s kontinuiranim porastom prihoda. Promijenjeni uvjeti donijeli su nove izazove (u prvom redu potrebu efikasnog upravljanja i financijske odgovornosti) na koje postojeći model neprofitnih organizacija nije mogao odgovoriti. Zbog neodgovornosti i nedovoljne stručnosti upravljačkog kadra, mnogi su klubovi tijekom I980-ih nagomilali dugove, a javni su izvori sredstava (najčešće 
gradski proračuni) doživljavani kao sigurno rješenje za izlaz iz nezavidne financijske situacije. To je središnje vlasti navelo da nizom zakona propišu obvezu preoblikovanja klubova u tržišne subjekte, u potpunosti neovisne o javnim sredstvima.

U Italiji je zakonom iz 1981. određeno preoblikovanje profesionalnih nogometnih klubova u dionička društva, a svaka je dobit morala biti reinvestirana u sportsku aktivnost. Tijekom 199o-ih ukinuta je zabrana isplate dividende dioničarima i zabrana ulaganja dobiti u ostale nesportske djelatnosti, ali uz obvezu reinvestiranja IO\% dobiti u nogometne akademije za razvoj mladih nogometaša. U Engleskoj su svi prvoligaški klubovi od 1982. ustrojeni kao društva kapitala. U Španjolskoj je 199o., nakon neuspješnog pokušaja države da tzv. Planom sanacije 1985. uvede financijsku disciplinu u klubove, donijet Zakon o sportu s obvezom preoblikovanja profesionalnih nogometnih klubova $\mathrm{u}$ privatne subjekte, posebno uređene za područje sporta (osim klubova Athletic Bilbao, FC Barcelona, CA Osasuna i Real Madrid koji su ustrojeni po tzv. "socios" modelu jedan član - jedan glas, tj. svi članovi kluba imaju pravo glasa).

U Njemačkoj je situacija donekle specifična, budući da postoje četiri različita pravna oblika. Od 1998. klubovi mogu biti ustrojeni u nekom od oblika trgovačkog društva. No, većina se klubova nije odlučila na direktno preoblikovanje, već su klubovi-udruge osnivali trgovačka društva kapitala u koja su kao uloge unosili cijelo poduzeće, ili profesionalni pogon kao ustrojbeni dio poduzeća.

Ustroj klubova, kako u Hrvatskoj tako i u EU zemljama, određuje njihov porezni položaj. Ukoliko se radi o neprofitnim organizacijama, primjenjuju se porezne odredbe koje im omogućuju povoljniji porezni položaj (razna izuzeća u oporezivanju dohotka i dobiti, snižene stope iliizuzeće u sustavu PDV-a). Radili se o trgovačkom društvu, pravila oporezivanja su jednaka ostalim gospodarskim subjektima.

Izraženiji su problemi nelegalnih financijskih aktivnosti direktno ili indirektno povezanih s oporezivanjem (FATF, 2009.). Rastući ekonomski značaj sporta, uz globalizaciju, posebice $u$ nogometu, osim pozitivnih donosi i negativne posljedice. Raznovrsni novčani tokovi i transakcije, te veliki broj sudionika pridonose povećavanju rizika od nelegalnih aktivnosti (pranje novca, korupcija, utaja ili izbjegavanje poreza, registracija $u$ zemljama s povoljnijim poreznim stopama, porezni prekršaji). Jedna od takvih rizičnih transakcija je i transfer igrača.
Premda je tema nelegalnih aktivnosti s poreznog gledišta u sportu vrlo bitna, zahtijevala bi posebnu, podrobniju analizu i nije predmetom ovoga rada, ali svakako može ukazati na određene zaključke.

\section{ZAKLJUǦGI}

\section{STATUS PROFESIONALNIH SPORTSKIH KLUBOVA I PREOBLIKOVANJA UDRUGA U S.D.D.}

Svaki profesionalni sportski klub može odlučiti koji pravni ustroj najbolje odgovara njegovom poslovanju i potrebama. Bez obzira na ustroj, klub može obavljati gospodarsku djelatnost koja podliježe porezu na dobit, odnosno obvezi ulaska u sustav PDV-a, što je sve u nadležnosti Porezne uprave.

Upitno je može li se profesionalni sportski klub u najvećem dijelu financirati iz javnih izvora i istovremeno obavljati gospodarske djelatnosti (sponzorstva i oglašavanje, transferi, prodaja ulaznica, tv-prava i sl.), a da pritom ne narušava načela tržišnog natjecanja i pravednih i ujednačenih uvjeta sportskih natjecanja.

Potrebno je stvarati uvjete za znatnije financiranje profesionalnih sportskih klubova (ne samo nogometnih) tržišnim i samofinancirajućim aktivnostima. To bi istodobno omogućilo preusmjeravanje određenog dijela javnih sredstava prema ostalim ciljnim skupinama i sportskim djelatnostima u nadležnosti lokalnih vlasti. Taj proces zahtijeva znatan napor institucija vlasti na svim razinama, ali i zalaganje cijelog društva. Ponajprije se to odnosi na borbu protiv korupcije unutar sportskih organizacija, namještanja utakmica i nasilja na sportskim priredbama, kako bi se stvorili osnovni preduvjeti za veće zanimanje publike, sponzora i privatnih investitora.

\section{TRANSPARENTNOST U POSLOVANJU I FINANCIJSKOM IZVJEŠTAVANJU}

Sustav financijskog izvještavanja profesionalnog sportskog kluba - bez obzira na njegov ustroj - treba biti transparentan i mora pružati objektivnu i realnu sliku financijskog položaja i poslovanja. Budući da se godišnje financijsko izvješće udruga i dioničkih društava znatno razlikuje, sa stajališta transparentnog praćenja profesionalnih sportskih klubova posebnim bi propisom trebalo definirati jedinstveni sadržaj financijskih izvješća kako bi bila usporediva i kako bi se mogla jedinstveno pratiti. Dok su godišnja revizorska izvješća sportskih dioničkih društava javno dostupna putem sudskog registra, Ministarstvo financija čim prije treba uskladiti propise o financijskom izvještavanju neprofitnih organizacija kojima će se i financijski izvještaji sportskih udruga (koje primaju i dotacije iz javnih izvora - 
proračuna jedinica lokalne samouprave), a koji se dostavljaju Ministarstvu, učiniti dostupnima javnosti. Porezni obveznici imaju pravo znati kako se troše njihova sredstva, bilo putem Registra neprofitnih organizacija i/ili Registra udruga.

\section{OPOREZIVANJE I TRANSFERI}

Aktivnosti vezane za transfere igrača, uz ostvarivanje visokih prihoda, ne mogu se - prema svim ekonomskim kriterijima - smatrati neprofitnom djelatnošću. Porezna bi uprava zbog narušavanja načela porezne pravednosti i jednakosti (ali i gubitka potencijalnih poreznih prihoda), trebala utvrditi radi li se o obavljanju gospodarske djelatnosti i o tome donijeti rješenje. Profesionalnim sportskim klubovima Zakon o sportu omogućuje da budu udruge građana, ali s obzirom na odredbe Zakona o porezu na dobit, $\mathrm{u}$ svakom je pojedinačnom slučaju potrebno preispitati je li riječ o obavljanju profitne ili neprofitne djelatnosti, odnosno o obvezi plaćanja poreza na dobit.

Oporezivanje transfera igrača, odnosno naknada za taj prelazak kao predmet oporezivanja nije nigdje izričito naveden (ni $\mathrm{u}$ hrvatskom Zakonu o PDV-u, ni $\mathrm{u}$ europskoj Direktivi o PDV-u), ali iz sadržaja te transakcije, uz primjenu odredaba i definicija pojma usluge i poduzetnika odnosno poreznog obveznika, nedvojbeno proizlazi da se radi o obavljenoj usluzi koja je predmet oporezivanja. Ministarstvo financija bi jasnim i nedvojbenim očitovanjem, te preciznim zakonskim određenjem trebalo to i utvrditi, pa prema tim odredbama i tumačenjima i postupati.

Zakonom o porezu na dohodak jasno je određeno što se smatra dohotkom i tko su obveznici poreza, a zadatak Porezne uprave je da taj porez zaista i naplati.

\section{REGULACIJA TRANSFERA}

FIFA $^{\text {I4 }}$ je uspostavila on-line Sustav za transfere igrača (Transfer Matching System - TMA) za razmjenu podataka koji omogućuje bržu, jednostavniju i transparentniju realizaciju transfera. Uveden je početkom 2008. i danas ga koristi svih 208 članica FIFA-e i preko 4.600 klubova. Osim što omogućuje detaljan uvid i vrednovanje ugovora, Sustav mora sadržavati i odredbe o financijskim transakcijama, odnosno mora se točno iskazati izvor sredstava i kasnija namjena. Za ispravno proveden transfer klubovi moraju iskazati niz podataka o sudionicima (klubovima, igračima), vrsti transfera te o plaćanju (matične banke platitelja i primatelja naknade, iznos i datume isplate), s ciljem veće transparentnosti i uspostave jedinstvenog sustava za praćenje transfera $\mathrm{i}$ jednoobraznosti u njegovoj provedbi.

Na stranicama Hrvatskog nogometnog saveza ${ }^{15}$ nalaze se propisi vezani uz transfere (Pravilnik o radu posrednika u transferima igrača, Licencirani posrednici u transferima igrača, Uvjeti za pristupanje ispitu za stjecanje zvanja licenciranog posrednika u transferima igrača).

Iz svega proizlazi da postoji dostatan normativni okvir i pravila vezana za transfere igrača, ali je nužna suradnja najodgovornijih tijela državne uprave (Ministarstva znanosti, obrazovanja i sporta i Ministarstva financija) i sportske zajednice na primjeni zakona i transparentnoj provedbi svih aktivnosti, posebice onih vezanih za oporezivanje. Naime, budući da sportske aktivnosti amaterskih i profesionalnih nogometnih klubova $\mathrm{u}$ najvećem dijelu financiraju hrvatski porezni obveznici, za uzvrat bi im trebalo pružiti ne samo uspješne sportske rezultate, nego i fair play izvan sportskih terena. 


\section{LITERATURA}

Ascari, G. i Gagnepain, P., 20o6. Spanish Football. Journal of Sports Economics, 7(I), str. 76-89.

Baroncelli, A. i Garuso, R., 20II. The Organization and Economics of Italian Serie A: a brief overall view. Rivista di diritto ed economia dello sport, 7(2), str. 67-85.

Delloite, 2013. Football Money League. Manchester: Sports Business Group at Deloitte.

Dremel, N., 20II. Poslovanje športske udruge. Računovodstvo, revizija i financije, (5), str. 60-70.

European Commission, 20II. Developing the European Dimension in Sport. Dostupno na: <http://ec.europa. eu/sport/news/communication-on-sport-adopted en.htm> [pristupljeno 20. 2. 20I3.].

European Commission, 2013. The Economic and Legal Aspects of Transfers of Players. Dostupno na: $<\mathrm{http} / / /$ ec.europa.eu/sport/library/documents/f-studies/ study-transfers-final-rpt.pdf $>$ [pristupljeno 20. 2. 2013.].

FATF, 2009. Money Laundering through the Football Sector. [pdf] Paris: The Financial Action Task Force. Dostupno na: <http://www.fatf-gafi.org/media/ fatf/documents/reports/ML\%2othrough\%2O the\%2OFootball\%2oSector.pdf $>$ [pristupljeno 26. veljače 20I3.].

Friganović, M., 20Io. Oporezivanje transfera športaša u RH. Poslovni savjetnik, 15. I. 20Io. Dostupno na: <http://www.poslovni-savjetnik.com/racunovodstvoporezi/oporezivanje-transfera-sportasa-u-rh $>$ [pristupljeno 26. veljače 20I3.].

Gómez, S., Martí, G. i Opazo, M. 2008. The structural characteristic of Sport Organizations: Differentiation within Elite spanish professional Football club. Working paper [online] Dostupno na: <http://www. iese.edu/research/pdfs/di-o75I-e.pdf > [pristupljeno 26. veljače 2013.].

IJF, 20I2. Projekt Financiranje sporta u Republici Hrvatskoj s usporednim prikazom financiranja u Europskoj uniji. Dostupno na: <http://public.mzos.hr/Default. aspx?sec=2379> [pristupljeno 26. veljače 2OI3.].

Ivkošić, M., 20Io. Pravni ustroj nogometnih klubova u Republici Hrvatskoj. Zbornik radova Pravnog fakulteta u Splitu, 47(2), str. 359.-385.

Javor, Lj., 2007. PDV i naknade za prijelaz igrača. Računovodstvo, revizija i financije, (Io), str. II9.

Jelić, H., 20Io. Oporezivanje transfera nogometaša PDV-om. TaxFlash [online] Dostupno na: <http:// www.zgombic.hr/UserDocsImages/TaxFlash/ TaxFlash_02_20Io.pdf> [pristupljeno 26. veljače 20I3.].

Kelly, K., Lewis, R. i Mortimer, T.,R., 2012. In Football We Trust? International Journal of Business and Social Science, 3(8), str. 243-254.

Klauški, T., 2007. Tko su neformalni vlasnici nogometnih klubova. Poslovni dnevnik, 7.12.2007. Dostupno na: 〈http://www.poslovni.hr/after5/tko-su-neformalnivlasnici-nogometnih-klubova-63307> [pristupljeno 26. veljače 20I3.].

Legge del 23 marzo 198I, n. 9I. Gazzetta Ufficiale del 27 marzo I98I, n. 86.

Lončarić-Horvat, O., 20Io. Šport i porezno pravo. Pravo i porezi (5), str. 16-19.

Ministarstvo financija. Računovodstvo neprofitnih organizacija. Dostupno na: 〈http://www.mfin.hr/hr/ neprofitno-racunovodstvo> [pristupljeno 26. veljače 20I3.].

Ministarstvo financija. Uputa o primjeni članka $7 \mathrm{I}$. Uredbe o računovodstvu. Dostupno na: 〈http://www. mfin.hr/adminmax/docs/Uputa\%200\%20primjeni\%20 clanka\%2071.\%2O \%2OUredbe\%200\%2oracunovodstvu\%2O neprofitnih\%2oorganizacija.pdf> [pristupljeno 26. veljače 20I3.].

Pravilnik o djelokrugu i načinu rada Povjerenstva za profesionalne športske klubove, NN II/O7. Zagreb: Narodne novine.

Pravilnik o načinu i rokovima podnošenja akata Povjerenstvu za profesionalne športske klubove, NN II/O7. Zagreb: Narodne novine.

Pravilnik o Registru profesionalnih športskih klubova, NN II/O7. Zagreb: Narodne novine.

Registar udruga. Dostupno na: 〈http://www.appluprava. $\mathrm{hr} /$ RegistarUdruga/> [pristupljeno 26. veljače 20I3.].

Rudd, J. Marcus, 2012. The Impact Governance and Club Structure has on a Team's Spending Power: A Case Study on the German Bundesliga. Economics Theses. Paper 86. Dostupno na: <http://soundideas. pugetsound.edu/economics_theses/86.> [pristupljeno 26. veljače 20I3.].

Stapić, S., 2012. Nogometni ples milijuna, a u proračunu ni lipe. Slobodna Dalmacija, 23. 7. 2012. Dostupno na: <http://www.slobodnadalmacija.hr/Novosti/ Crnakronika/tabid/70/articleType/ArticleView/ articleId/I8I799/Nogometni-ples-milijuna-a-uproraunu-ni-lipe.aspx > [pristupljeno 26. veljače 20I3.].

Vuković, A., 20II. Stečajni plan kao treći model za športske klubove. Zbornik radova Pravnog fakulteta $u$ Splitu, 48(4), str. 63-934.

Zakon o porezu na dobit, NN 177/04, 90/05, 57/06, I46/O8, 80/IO, 22/I2. Zagreb: Narodne novine.

Zakon o porezu na dodanu vrijednost, NN 47/95, I06/96, I64/98, I05/99, 54/oo, 73/o0, 48/O04, 82/04, 90/05, 76/07, 87/09, 94/09, 22/12, I36/12. Zagreb: Narodne novine.

Zakon o porezu na dohodak, NN I77/O4, 73/o8, 80/Io, II4/II, 22/I2, I44/I2. Zagreb: Narodne novine.

Zakon o sportu, NN 7I/O6, 50/o8, I24/IO, I24/II, 86/I2. Zagreb: Narodne novine.

Zakon o udrugama, NN 88/oI, II/o2. Zagreb: Narodne novine. 